Journal of the Bangladesh Association of Young Researchers (JBAYR), Volume 1, Number 1, January 2011, Page 127-132

ISSN 1991-0746 (Print), ISSN 2220-119X (Online), DOI: 10.3329/jbayr.v1i1.6842

\section{Short Communication \\ PLAGIARISM AT A GLANCE: A CASE STUDY OF UNIVERSITY OF THE PUNJAB}

\author{
Haseeb Ahmad Piracha \\ Punjab University Library, University of the Punjab, \\ Lahore, Pakistan \\ E-mail: haseeb@library.pu.edu.pk
}

The purpose of this writing is to guide and facilitate the students, faculty members as well as professionals of University of the Punjab to identify ways and means to prevent plagiarism among academic writing and to develop an awareness of ethical writing. In addition this article will highlight the efforts being carried out by the Higher Education Commission of Pakistan combined with the University of the Punjab in order to curtail plagiarized and questionable writing in academic research.

Plagiarism is defined as "taking and using the thoughts, writings and inventions of another person as one's own" (Concise Oxford Dictionary). (Wikipedia) explains that within academia, plagiarism by students, professors or researchers is considered academic dishonesty or academic fraud and offenders are subject to academic censure. A large number of books, articles and entire journals have been published dealing with various aspects of plagiarism, conference presentations, online discussions and entire conferences, blogs, online discussions are available for guidance and awareness in order to promote ethical writing.

Pecorari (2008) explains that Plagiarism has long been regarded with concern by the university community as a serious act of wrongdoing threatening core academic values. There has been a perceived increase in plagiarism over recent years, due in part to issues raised by the new media, a diverse student population and the rise in English as a lingua franca.
In the University of the Punjab first initiative about plagiarism checking was floated in May, 2007 with the announcement of H.E.C that iTenticate antiplagiarism software had been acquired in order to check plagiarism among research writings of University of the Punjab. Only one license was made available for University of the Punjab and Chief Librarian, Punjab University Library was nominated as focal person with a Sr. Deputy Chief Librarian to get training and password of the software from H.E.C. A training session was held at H.E.C Islamabad in July, 2007 for all public sector universities of Pakistan in order to give briefing about iThenticate software. The H.E.C spokesman highlighted the importance of anti-plagiarism software and announced that H.E.C's goal is to combat plagiarism effectively in an academic environment in all institutions of Pakistan while ensuring that stealing someone's intellectual property is unethical and can lead to many consequences. He further added HEC has selected an internationally recognized anti-plagiarism software/service to distinguish original text from plagiarized material.

University of the Punjab started checking plagiarism with the help of iThenticate software and prepared only two item agenda for all university departments.

1. Every teacher, scholar or student will provide a soft copy of his/her article, report or thesis to the Chief Librarian, Punjab University Library for plagiarism checking.

2. No thesis can be accepted for M.Phil/Ph.D until or unless it has been checked by the software iThenticate.

In September, 2007 H.E.C also announced a plagiarism policy on the requests of public sector universities which can be consulted on the website www.hec.gov.pk. iTenticate plagiarism checking software was being used up to the end of 2008 in the University of the Punjab in order to check the plagiarism among theses, articles, research reports of students, faculty members and researchers. The process of checking was quite simple every scholar had to provide a letter from his/her supervisor verifying his/her work with a soft copy. After checking original work through that software he was issued certificate showing similarity percentage of the work. A large number of articles M.Phil/Ph.D theses had been checked through this software. A statistical data is presented at Table 1 and Figure 1. 
Table 1: Statistical Report of Thesis \& Articles Checked through Ithenticate

Plagiarism Software

\begin{tabular}{|c|c|c|c|c|}
\hline $\begin{array}{l}\text { Sr. } \\
\text { No. }\end{array}$ & Department & No of Articles & $\begin{array}{l}\text { No of Ph.D. } \\
\text { Thesis }\end{array}$ & $\begin{array}{l}\text { No. of } \\
\text { M.Phil } \\
\text { Thesis }\end{array}$ \\
\hline 1 & High Energy Physics & 32 & & \\
\hline 2 & Chemistry & 3 & & \\
\hline 3 & English & & 1 & \\
\hline 4 & $\begin{array}{l}\text { Institute of } \\
\text { Administrative Sc. }\end{array}$ & & & 15 \\
\hline 5 & $\begin{array}{l}\text { Institute of Education } \\
\text { and Research. }\end{array}$ & 48 & & \\
\hline 6 & $\begin{array}{l}\text { Institute of Quality } \\
\text { Management }\end{array}$ & 27 & & \\
\hline 7 & Mass Communication & 8 & & \\
\hline 8 & Economics & 13 & & \\
\hline 9 & Philosophy & 3 & & \\
\hline 10 & Political Science & & & 35 \\
\hline 11 & Social Work & 3 & & \\
\hline 12 & $\begin{array}{l}\text { School of Biological } \\
\text { Science }\end{array}$ & & 1 & \\
\hline 13 & $\begin{array}{l}\text { Mycology Plant } \\
\text { Pathology. }\end{array}$ & & 7 & \\
\hline 14 & Zoology. & & 2 & \\
\hline
\end{tabular}

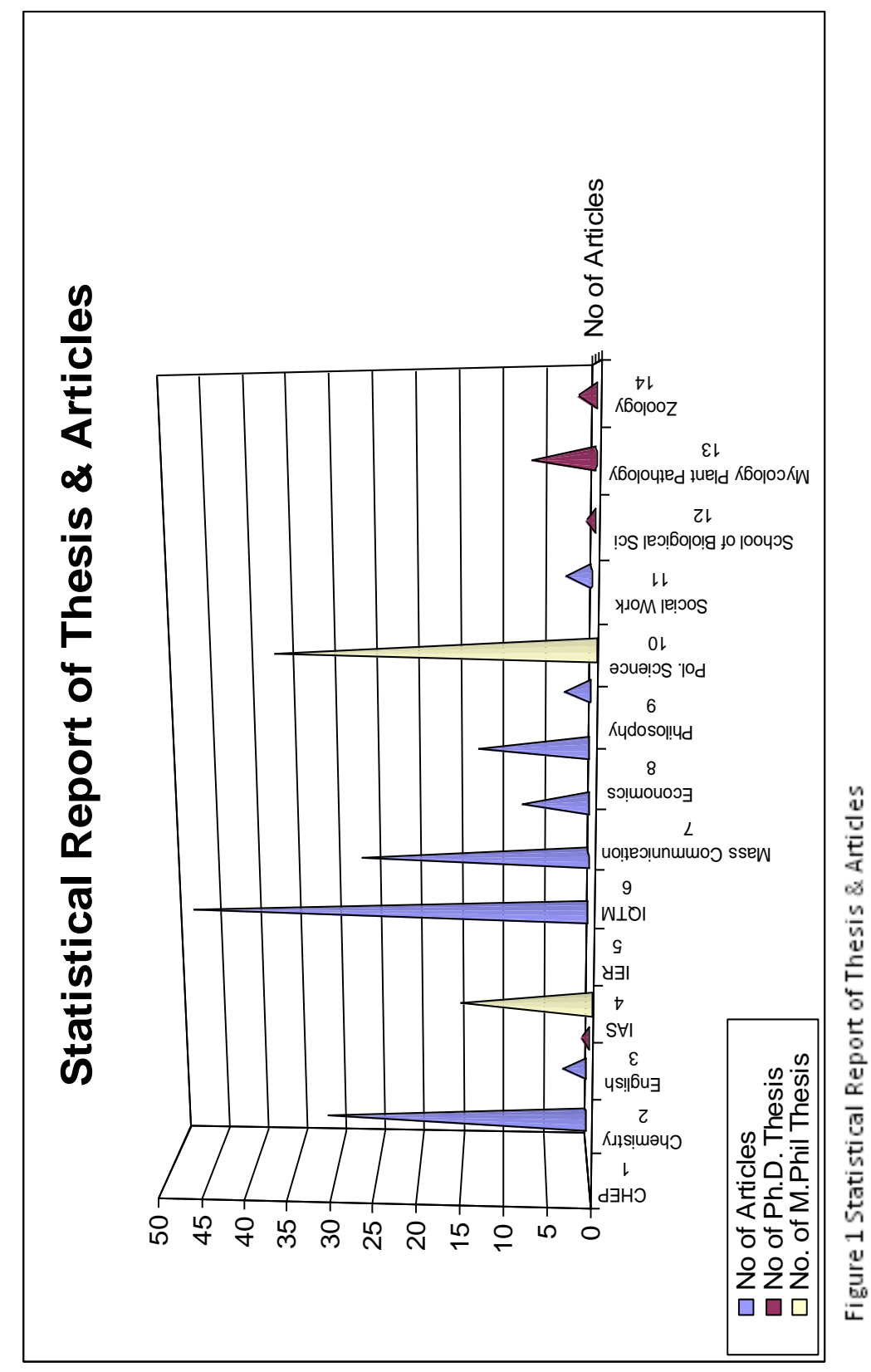


Only one license was provided to the University of the Punjab by the H.E.C. All the time there was tremendous pressure of articles and theses checking on that wing which provided plagiarism checking certificates to the scholars. After realizing this fact H.E.C took another step and hired (Turnitin) service for plagiarism checking. In this service all faculty members who are involved in imparting Ph.D studies are allowed to get access of Turnitin in order to check plagiarism at their own of scholars' work of their related disciplines.

In July, 2009 the Chief Librarian University of the Punjab was directed to create accounts of all faculty members which are involved in imparting Ph.D studies after acquiring basic information about them duly verified by the head of the departments. This huge project was again handed over to the Chief Librarian who had been nominated as focal person for antiplagiarism service. H.E.C nominated Chief Librarian as Administrator and it is the duty of the Administrator to create accounts of Instructors which are faculty members and to arrange training sessions of Turnitin for them.

After getting information regarding first name, last name and email address of the related faculty members, instructors' accounts were created and a series of training sessions have been conducted for faculty members in order to familiarize them with Turnitin software. For this session a video of step by step functions of Turnitin has also been prepared and after training this video has been sent to the email of participants for future guidance. However, online training, manuals and quick guide are also available on www.turnitin.com.

One hundred sixty instructors have been created who are directly involved in Ph.D study programmes of different departments. All are properly trained to check plagiarism and issue certificates of similarity to this effect. Some views and penalties are as under for the guidance and help of scholars.

Students and faculty members need to know how very seriously plagiarism is regarded in the academic community, and how heavily it is penalized. A study of university plagiarism policies in Britain, the United States and Australia (Pecorari, 2001) found provisions for punishing plagiarists by lowering their grades, possibly to zero, either on the plagiarized work or in the class for which it was done, by suspending or expelling them from the university, or by denying or revoking degrees (Baty, 2004) for a case in which a degree was denied for plagiarism and (Wasley, 2007), for the revocation of a degree which had been awarded some years earlier.

Higher Education Commission of Pakistan and University of the Punjab are committed to abolish plagiarism from academic writings and now there is a wave of awareness under which scholars are being guided by the instructors that how to avoid coping others work under their names.

\section{REFERENCES}

- Baty, P. (2004). Plagiarist student to sue university. Times Online. Available at www.timesonline.co.uk.

- Concise Oxford Dictionary. Oxford. Clarendon Press.

- Pecorari, D. (2001). Plagiarism and international students: How the Englishspeaking University responds.

- Pecorari, D. (2008). Academic writing and plagiarism: a linguistic analysis. United Kingdom: Continuum.

- Wasley, P. (2007). Ohio University revokes degree for plagiarism. Chronicle of Hieher Education, vol. 53 (31):p.10

- $\quad$ www.hec.gov.pk

- $\quad$ www.wikipedia.com 